\title{
Генноuнженерная биотехнология
}

$\therefore$ 工K 579.852 .11

\author{
ВЕКТОРЫ ЭКСПРЕССИИ НА ОСНОВЕ ПРОМОТОРОВ ГЕНОВ \\ PHO3 И РНО5 ДРО\%̈IREЙ SACCHAROMYCES CEREVISIAE: \\ КОНСТРУИРОВАНИЕ, СРАВНИТЕЛЬНАЯ ОЩЕНКА \\ ЭФФЕКТИВНОСТИ, ИСПОЛЬЗОВАНИЕ ДЛЯ СУПЕРПРОДУКЦИИ \\ ФОСФОРИБОЗЩЈА МИНОИМИДАЗО.ТКАРБОКСИТАЗЫ
}

IR. В. Останин, Т. М. Смирнова, $\Lambda$. Н. Мясников,

Ж. А. Гединайте, К. В. Саснаускас, М. Н. Смирнов

Введение. Один из определяющих моментов в работе по созданию си-

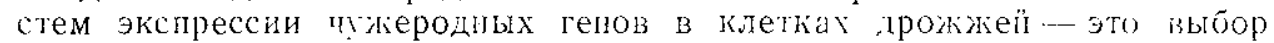
дрожжевопо промотора, способног обеспечнть высокую продуктизность

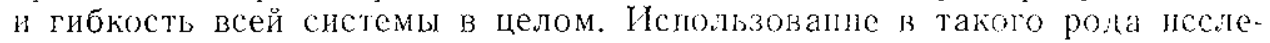
дования промоторов структуриых генов репрессибельной и коистнту-

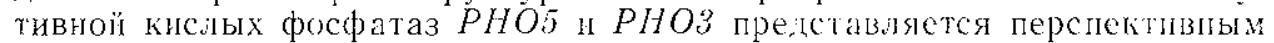
по ряду причнн. Эти гены клонированы в составе единого фрагмента

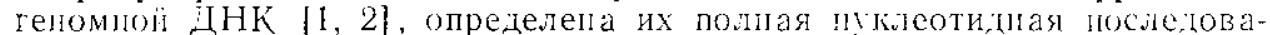

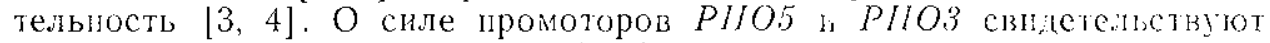
зысокие уровии ститеза кислых фосфатаз в црожысвых клетках, составпяющие около $1 \%$ облего белка [5]. Akтивност промотора re!sa PHO5 регулируется концентрацией неорганисского фосф)ата в культуральнй среде [6]. Регуляториая система, посредством которой активир:ется

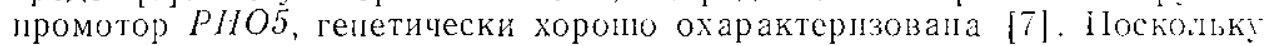
продуктами PIIO5 н $P$ HOЗ являются секретирусмые белки, при созда-

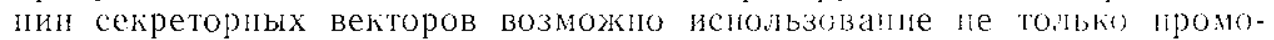
торов, по и фрагмептон кодирующих областеї этих генов, соответспвуюцих сигшальным пегтндам.

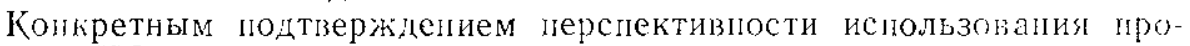
мотора PHO5 для полученця штаммов дрожжей, продуцируюших пукеродные белки, пвляются успешиыс работы по экспрессии по: его конгролем гелов лейкоцитарного нитерферона $[8,9]$, поверхностиого анти гена вируса гепатита |10] и ряда других. Промотор гена PIIO3 panee в аналогичы исслецьзания ислользовап не был.

Первой задачей пастоящей работы являлось конструированне бактериалылх плазмид, пазываемых пами «векторами экслресспи», которые могут быть ислользозаны дыя слияния разлиных генов с делециопиыми производыымл промоторов PHO5 или PHO3, а также с фрагмептом PHO5, содержащим сигыалы термиации трапскриции и полиаденилирования, с последующим перепосом полученных копструкций в дрожжевые плазмнды. Для сравпителынй оцепки псрспективпости нслользования этих некторов при решенин биотехнологических задач была изучела экспрессия гена $A D E 2$ поп контролем промоторов PIIO лі $P / / O 3$ в прожжевых клетках.

Ген $A D E 2$ дрожжей-сахаромицетов кодирует структуру фосфорибозинампіонмидазо-карбоксилазы ( фермептов биосинтеза пуриновых нуклеотидов. Этот ген к пастоящему времсни клонировап [11] иі секвенирован [12], разработап простой спектрофотометрический метод определепия активности АИР-карбоксилазы в дрожжевых экстрактах [13]. Характерной особенностью штам- 
мов, частично или полностью лишенных активности АИР-карбоксилазы, является паличие в клетках красного пигмента [14]. Это дает возиожность качественп оценивать уровень экспрессии гена $A D E 2$ по окраске колоний. Перечисленные данные свидетельствуют об удобстве использования уровня экспрессии этого гена в качестве критерия эффективности дрожжевых промоторов.

Материалы и методы. В работе исиользовали стандартные лабораторные штаммы Escherichia coli HB101 и JM103. Культивирование бактерий проводили на среде LB ( $1 \%$ пептона, $0,5 \%$ дрожжевого экстракта, $1 \% \mathrm{NaCl}$ ) с добавкой бснзилпенициллина $(500000$ ед/л) или тетрациклина $(15$ мг/л). Для проверки бактериальных штаммов на наличие активности $\beta$-галактозидазы использовали среду LB, содержащую 5-бромо3 -хлороиндолил- $\beta$-галактозид и $\beta$-изопропилтиогалактозид (по 40 мг/л). Трансформацию бактсрий, выделение и рестрикционный анализ плазмид проводили по [15]. В работе использовали фрагмент Кленова, ДНК-лигазу и рестрнктазы EcoRV, SmaI и DraI («Amersham», Англия), рестриктазы EcoRI, BamHI, Sall, HindIII, PstI (HПО «Фермент», Вильнюс), а также ряд других рестриктаз, любезно предоставленных нам А. А. Янулайтисом (НПО «Фсрмент»). Нуклеотидную последователыпость определяли методом Сэнджера [16], используя в качестве праймера олигонуклеотид структуры AGTATGGCTTCATCTCTC, комплементарный участку промоторной области гена PHO5, прсдоставленный нам А. Хиннсном («Сiba-Geigi», Швейцария), нли стапдартпый 17-членный олигонуклеотид для системы фагов M13mp, синтезированный и любсзно предоставленный нам В. А. Вейко (ВНИИгенетика, Москва), Плазмида pYC1(PHO3PHO5), содержащая клонированныс гсны PHO3 и PHO5, также получена oт A. Хиннена, В работе использовали стандартный штамм S. cerevisiae DC5 (a his3 lou2 can1) и полученный на его основе мутант по гену $A D E 2$ p29-DC5, предоставленный нам Д. А. Гордениным (ЛГУ им. А. А. Жданова). Для выращивания дрожжевых штаммов пспо.пьзовали минимальную среду SC $(0,67 \%$ mpeпарата Yeast Nitrogen Base без аминокислот («Difco», CШАA), $2 \%$ глюкозы) с добавкаии адснина (10 мг/л), $L$-гистидила или $L$-лейцина (по $50 \mathrm{mr} / л$ ), а также полные среды ПЕП и ПЕПфО [17]. Трансформацио црожжей осуществляли согласно [18].

Дрожжсвые экстракты получали вскрытием клеток культуры, выращенной до окопчания логарифмической фазы роста при $30^{\circ} \mathrm{C}$, с помошью пресса Хьюза в $0,2 \mathrm{M}$ трис-фосфатном буфере ( $\mathrm{pH} 8,0)$, содержащем глицерин $(10 \%)$, дитиотреитол (1 мM), ЭДТА (1 мМ), фенилметилсульфоннлфторид (1 мМ). Активность АИР-карбоксилазы в экстрактах определяли с помощью мстода, описанного в работе [13]. Субстрат АИРкарбоксилазы карбоксиаминоимидазолриботия (КАИР) синтезирован сотрудниками лаборатории биохим. генетики ЛГУ им. А. А. Жданова В. Д. Домкиным и Т. Р. Костиковой. Концентрацию белка оцредсляии по методу Брадфорда [19].

Результаты и обсуждение. Начальным этапом работы являлось колструирование векторов экспрессии на основе промоторов PIIO5 и PHO3. При этом использовали делециониые производыые промоторпой области гена PHO5, получеппые следующим образом. Фрагмент этого lепа, ограпиченный сайтами рестрикции BamHI и Sall и содержаший промотор и пачало коцируюшей области (рис. 1), клонировали в фаговом векторе m13mp9. После гнцролиза репликативной формы рекомбилаптного фага но уникальному сайту рестрикции KpnI, переваривания экзопуклеазоӥ Bal31, репарации липких копцов ДНК фрагмептом Кленова, лигирования в присутствии лlпкеров EcoRI и трансформацин клеток $E$. coli выделяли однонитевую ДНҚ из 200 случайно выбрапных трапсформаптов. На основанин анализа нуклеотидной последовательпости $3^{\prime}$-копцевой области промотора $P H O 5$ в составе полученых рекомбпиатиых фаговых ДНК было отобрапо 12 делеционых пронзволіых промотора с положением конечных точек делеции -42, -35, -31, $-17,-2,-1,+12,+19,+23,+32,+46,+53$ от стартовой томки трансляции. Еще одіо делецнопное производное было получено в рсзультатс рестрикции BamHI-SalI-фрагмента гена PIIO5 по сайту Dral, расположепному в положепии +6 от инициирующего кодопа. Копепые точки делеций во всех случаях были фиксировапы присоедншенисм линкера EcoRI. Были сконструировашы векторы экспрессии пाа ослове 
шести картированых делеционных вариантов, коордипаты $3^{\prime}$-копцов которых приведены ниже:

$\begin{array}{lc}\text { Плазмида } & \begin{array}{c}\text { Положение конечнов точки } \\ \text { делеци относительно начала } \\ \text { коднрующей области }\end{array} \\ p A M 31 & -31 \\ p M S 46 & -17 \\ p N K 45 & -2 \\ p Y P 26 & -1 \\ p Y K 20 & +6 \\ p V Y 18 & +53\end{array}$

Схема конструировапия представлена па рис. 2.

Полученные векторы экспрессии на основе промотора PIIO5 можно разделить на три типа. Во-первых, это векторы, содержапие фрагменты гена PHO5 с положением делещии в области, соответствующей лидерному участку мРНK ( $p A M 31, p M S 46, p N K 45, p Y P 26)$. 3пачение этого участка для эффективной экспрессии генов в клетках эукариот

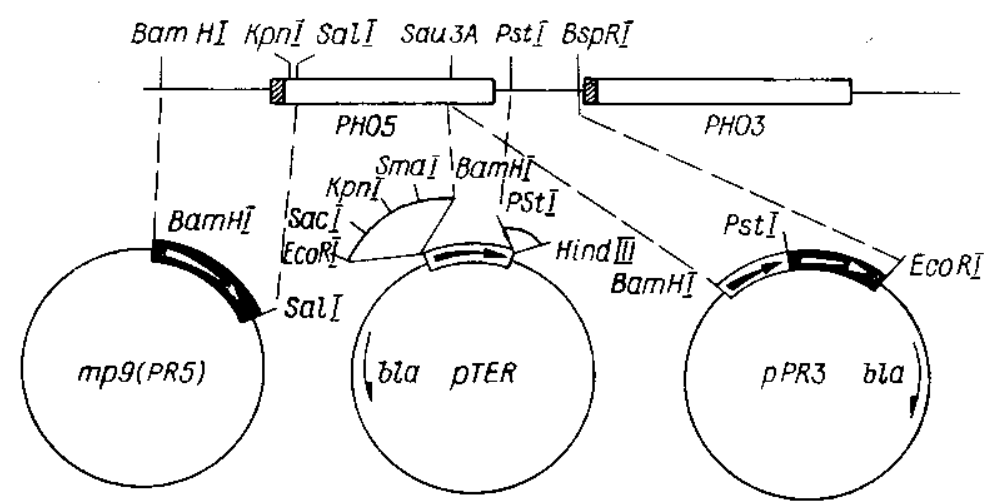

Рнс. 1. Частичная рестрикционная карта кластера генов PHO5 и $\mathrm{PHO3} \mathrm{(вверху)} \mathrm{(пря-}$ моугольниками выделены кодирующие участки генов, заштрихованные участки соответствуют лидерным областям белков) и клонирование фрагментов кластера генов PHO3 и PHO5, использованных при конструировании векторов экспрессии (внизу). Субклонированные фрагменты генов $\mathrm{PHO} 3$ и $\mathrm{PHO5,} \mathrm{использованнье} \mathrm{в} \mathrm{качестве} \mathrm{«пере-}$ носных промоторов», обозначены темными прямоугольниками со стрелкой. Sau3A-PstIфрагмент гена $P H O 5$, ислользованный в качестве «переносного терминатора транскрипцни», обозначен светлым прямоугольником со стрелкой. Стрелки указывают направление транскрипция

Fig. 1. Above: a partial restriction map of the $\mathrm{PHO} 3$ and PHO5 gene cluster. The coding regions of the two genes are represented by open boxes, the sequences coding for the signal peptides are indicated by striped boxes. Below: cloning of fragments of the PHO3 and PHO5 genes for the use in construction of the expression vectors. The fragments of PHO3 and PHO5 used as «portable promoters» are represented by black boxes with an arrow. The Sau3A-PstI fragment of the PHO5 gene used as «portable transcription terminators is shown by an open box with an arrow. The arrows indicate the direction of transcription

до настоящего времени остается не до конца ясным. Поэтому представляло интерес получить ряд делеционных производиых этого типа с тем, чтобы впоследствии сравнить их эффективность в одной модельной системе. Во-вторых, эло всктор рYК20, где сохранен инициирующий кодон PHO5, что делает возможным использовапие его для экспрессии генов, для которых инициация трапсляции с собственного ATG-кодона по каким-либо причинам невозможна или неудобна. И наконец, вектор $p V Y 18$, содержащий делеционное производное промотора PHO5 с участком гена, кодирующим структуру сигнального пептида, может быть использован для пюлучения секреторных дрожжевых векторов.

При конструировапии вектора экспрессии на основе промотора PHO3 использовали одно делеционное производное этого промотора, полученное следуюцим образом. Из плазмилы pYC1(PHO3PHO5) выделяли фрагмент ДНK, ограниченный сайтами рестрикции $\operatorname{Sau} 3 A$ п1 $B s p R I$. После присоединения $\mathrm{k}$ его тупому концу линкера EcoRI он 
был клопирован в составе бактериалыной плазмиды pUC19 (рис. 1). Сконструированый па основе выделенного фрагмента вектор экспрессин $p B G 10$ (рнс. 3) включает промоторлую область гена P/IO3 от -17 до - 370 пуклеотида, считая от ATG-кодопа. Граница этого фрагмента па $5^{\prime}$-конце выбрапа с учетом дапных, рапее полученых в папей лабораторин, согласпо которым сохрапение 370 пар оспований (п. о.) $5^{\prime}$-некопирующей области гена P/IO3 обеспечивает его полиоцепную экспрессию в составе мультикопийной пуазмиды.

Bсе получелые пами векторы экспрессии построены по общему план. Они содеркат делециопне пронзводное промотора rena PHOS
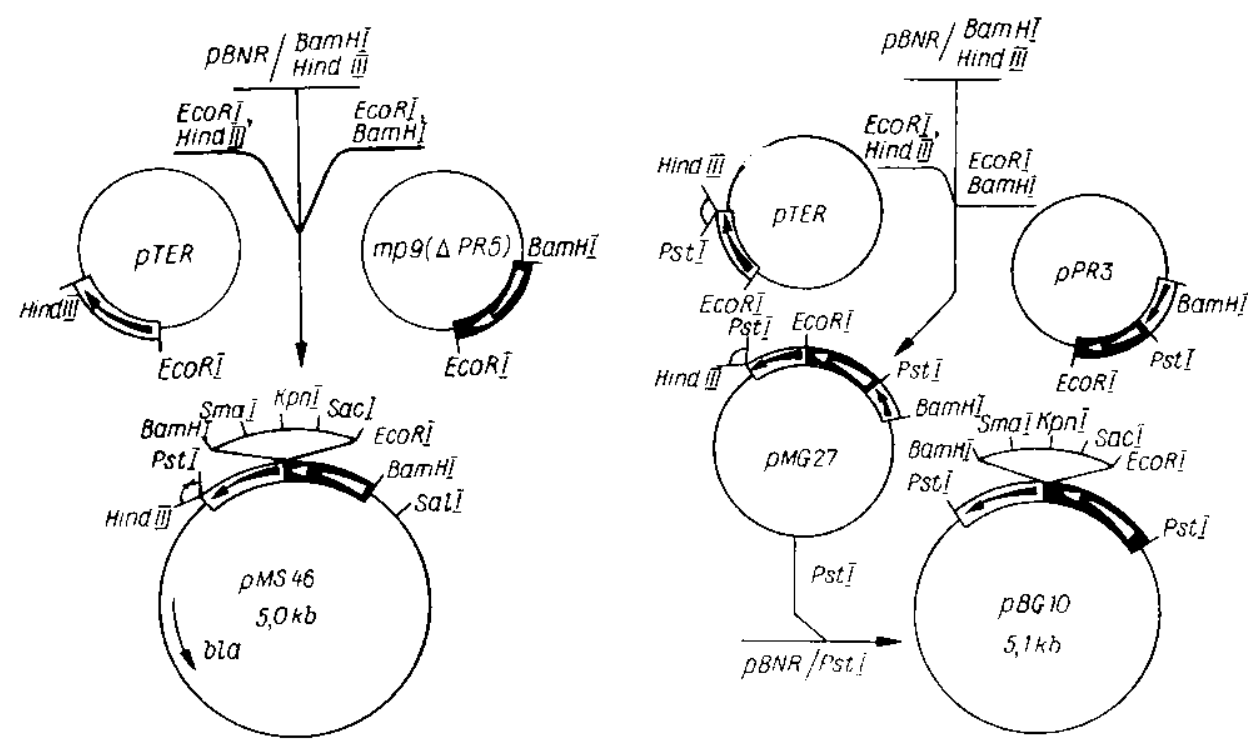

Рис, 2. Получение плазмнд экспрессин, содержащих промотор и терминатор гена PHO5, разделеные полилинксром, на примере одной из пяти однотипных плазмид-pMS46. Обозначения те же, тто па рис. 1. Стрелками показано направление транскрипции Fig. 2. The construction of the expression vectors containing the promoter and transcription terminator of the PHO5 gene with a polylinker fragment between them. The conventions are the same as in Fig. 1

PHс. 3. Конструирование плазмиды $p B G 10$. Обозначения, как на рис. 1

Fig. 3. The construction of the plasmid $p B G 10$. The conventions are the same as in Fig. 1

нии PHO3 и терминатор транскрипции PHO5 (рис. 1), одинаковым ббразом ориелтировапы и разделепы участком полилинкера плазмиды pUC19, включаюшим пять уникальлых сайтов рестрикции. При использовании этих векторов для экспрессии в клетках црожжей чужеродиых генов предусмотрепа следующая последовательпость операций: встраивапие коцирующей части иптересующего пас гепа в полилинкерпы участок и последующий перенос конструкции «промотор - коцирующая часть - терминатор» в один из бифупкционалыных бактериалыно-дрожжевых векторов. Альтерпативная стратегия, при которой все фупкциопалыныс элементы окончательпо̆ копструкции за исключением экспрессируемого гена собираются в составе дрожжевого челночного вектора, мепее удобла, поскольку такие векторы содержат ограниченпое число удобных для клопировапия уникальпых рестрикциопाых сайтов.

Для сравнителыюй оценки эффективпости использовапия полученных векторов была проделана работа по изучению экспрессин дрожжевого гелг $A D E 2$ под коптролем промоторов PHO5 и PIO3. Для получения фрагмента ДНК, содержащего кодирующую часть гепа $A D E 2$ без промоторной области, использовали сконструированые пами ранее плазмиды $p Y E(A D E 2)-3$ и $p L C A$, рестрикционшые карты которых приведепы иа рис. 4. В состав первой из них входит фрагмент ДНК XV хромосомы дрожжей длиной 3600 п. о., включающий кодирующую часть 
гена $A D E 2$, фланкированную достаточно протяжеными пуклеотидын ми последовательностями. В плазмияе $p L C A$ содержится структурная область гена за исключепием 14 п. о. с 3'-конца. K 5'-и 3'-копцам этого фрагмента присоединены линеры $B a m H /$ н Sall coornctcrbenio. Ipoмоторный участок гела делетирован в результате обработки экзолуклеазой Bal31. В результате анализа пуклеотндыой последовательности указанного фрагмента после переноса его в ЦНК фага $M 13 \mathrm{mp} 9$ п्амл установлено, что он содержит :ишь 5 п. о. $5^{\prime}$-лекоцирующей обlaсти гена $A D E 2$. Ha pис. 5 изображена схема конструирования I1:Iaзмнды pUC19(ADE2)-2, в состав которой входит фрагмент
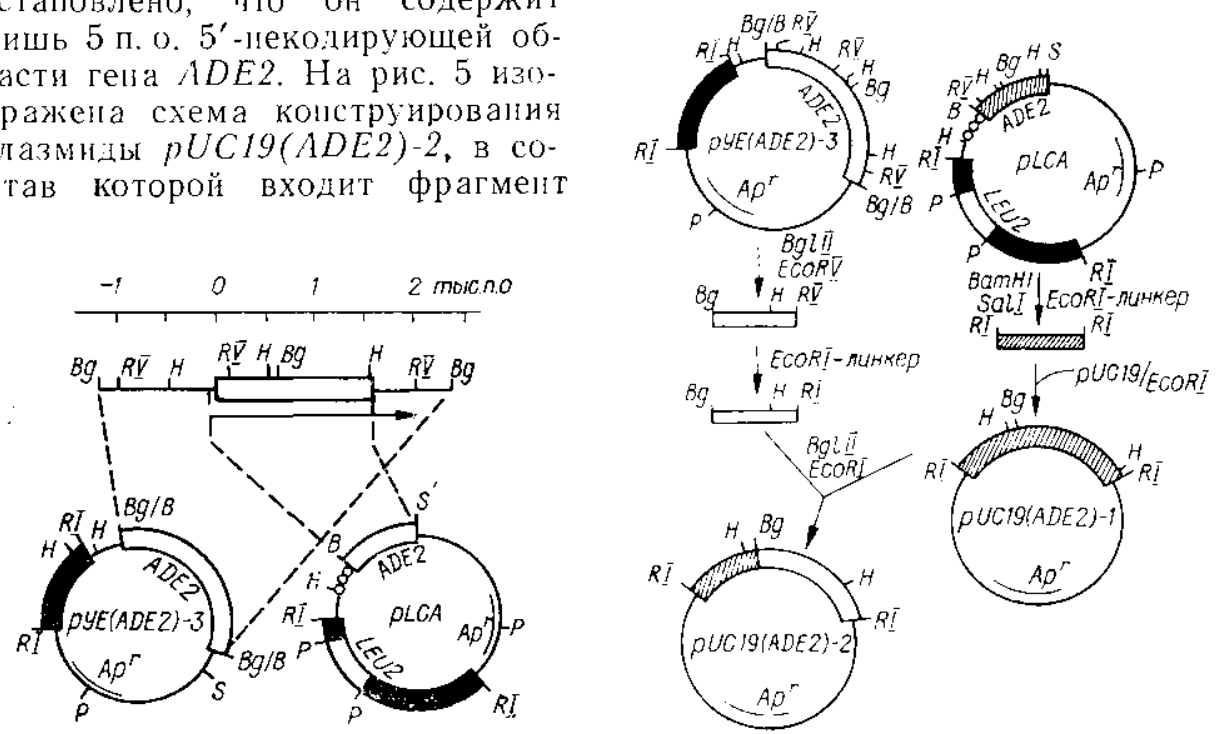

Pнс. 4. Строение плазмид $p Y E(A D E 2)-3$. $p L C A$ и вхолящего в их состав гена $A D E 2$ лрожжей-сахаромилетов. На схеме $A D E 2$ белым прямоугольником выделена кодируюпая тасть гсна, стрелкой обозначен фрагмент, использованный для встраивания в векторы жспрессни. Черными прямоугольниками обозначены фрагменты 2 мкм ДНК дрожжісін-сахароминстов, тонкой линией - ДНК pBR322, кружками - ДНК пентромерной ббласті III хромосомы дрожжей. Сокрапинные обознатсния сайтов рестрикции: $R I-$ ECORI, RV - ECORV, P-PSII, B-BamHI, H-HindIII, S-SalI, Bg-BgllI

Fig. 4. The structure of the plasmids pYE(ADE2)-3 and pLCA containing the yeast $A D E 2$ gene. The open box represents coding region of $A D E 2$. The arrow shows the part of $A D E 2$ present in the final constructions used for expression studies. The black boxes stand for rragments of $2 \mu \mathrm{m}$ DNA, thin line for $p B R 322$ DNA, the circles for the portion of yeast CEN3 DNA. The abbreviations of the restriction sites are EcoRI - RI, EcoRV$R V, P s t I-P, B u m H I-B$, Hindll $-H$, Sall $-S, B g l l l-B g$

Pис. 5. Схема конструирования плазмид $p U C 19(A D E 2)-1$ и $p U C 19(A D E 2)-2$. Белыми прямоутольниками изображены фрагменты $A D E 2$, получсииые из плазмиды $p Y E(\Lambda D E 2)-3$, заптрихованными - фрагмелты плазмпды $p L C A$. Остальные обозначситя те же, что на рис. 1

Fig. 5. Construction of plasmids $p U C 19(A D E 2)-1$ and $p U C 19(A D E 2)-2$. The fragments of $A D E$ ? gene originating from $p Y E(A D E 2)-3$ are represented by open boxes those from plasmid pLCA by striped boxes. The other designations are the same as in Fig. I

ДНК, включаюций кодирующую часть гепа $A D E 2$, а также 5 п. о. его $5^{\prime}$-лскодирующей и приблизительно 350 п. о. $3^{\prime}$-пекодируюпей областей.

Пля слияния структурной части гена $A D E 2$ с регуляторшыми областями PHO5 и PHO3 использовали скопструировапшы пाами векторы экспрессии $p M S 46$ и $p B G 10$. Плазмида $p M S 46$ coдержіи промотор PHO5 (размер фрагмешта 560 п. о., положелие целеции - 17 п. о. от пиициируюнего ко:ога), плазмига pBG10- промотор PHO3 (размер фрагмент 350 п. о., положелие делеции -17 п. о.). Гел $A D E 2$ выделя'lи из илазмиды $p U C 19(A D E 2)-2$ рестрикцией по сайтам EcoRI и встрағвали в одноименный сайт векторов эксирессии $p M S 46$ и $p B G 10$ в той же ориентации, что и промоторная и терминаторная области. Полу renшые копструкции «промотор PHO5 (или PHO3) - ADE2 - область тсрмннация транскрипцин $P / / O 5 »$ выделяли с помощью ограпиченпого

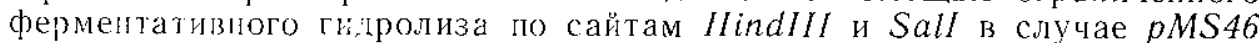

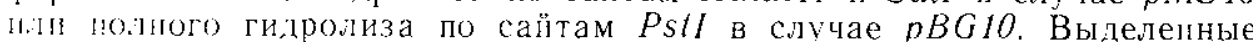


фрагменты клонировали в составе дрожжевого челиочного вектора $\rho J D B 207$. Выбор данного вектора для изучения экспрессии гена $A D E 2$ в клетках дрожжей обусловлен его высокой стабильностью и копийностью.

Полученными плазмидами $p T C 8$ и $p T L 1$ (рис. 6) трансформировали штамм дрожжей-сахаромицетов p29-DC5 (a ade2 his3 leu2), по.1ностью лишенный активности АИР-карбоксилазы и вследствие этого характеризующийся красной пигменталией колоний и полыым отсу-

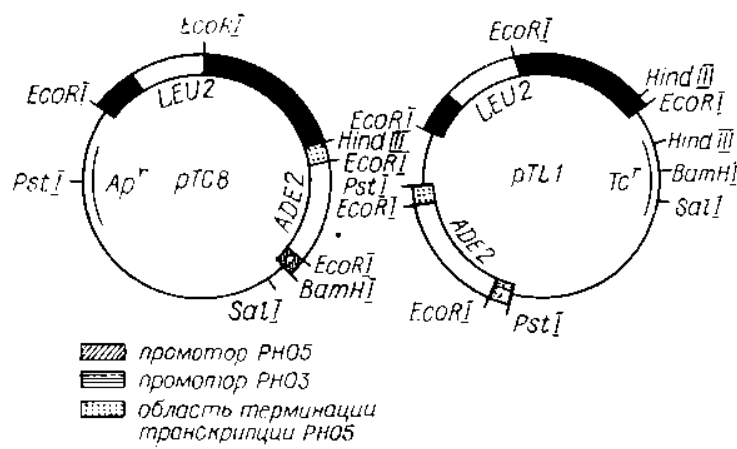

Рис. 6. Строение дрожжевых векторов $p T C 8$ и $p T L 1$. Обозначсния, кроме указанных, такис же, как на рис. 1

Fig. 6. The structure of the pTC8 and $p T L 1$ expression plasmids. De. signations, except for the mentio. ned, are the same as in Fig. 1

ствием способности расти на минимальной среде, не содержащей адепина. В результате каждой трансформации было отобрапо по 20 кионов, утративших ауксотрофность по лейцину. Все сни в отлнтне от штамма-реципиента имели белую окраску, характерпую для птамма дикого типа, и не имели ауксотрофности по аденину. Этот результат свидетельствует о функционировании гена $\triangle D E 2$ в клетках трапсформантов іод контролем промоторов структуріых генов кислых фосфатаз. Для количествепиой оценки уровней экспрессии гена были измерены величины удельной активности АНР-карбоксилазы в клеточных экстрактах полученных трансформантов (таблица).

\begin{tabular}{|c|c|c|}
\hline Штамм & Среда & $\begin{array}{l}\text { Удельная активность АИР-карбоксилазы } \\
\text { (мкмоли КАИР } \text { мин }^{-1} \cdot{ }_{\text {мг белка }}-1 \text { ) } 10^{3}\end{array}$ \\
\hline$D C 5$ & $\begin{array}{l}\text { ПЕП } \\
\text { ПЕПФО }\end{array}$ & $\begin{array}{l}1,6 \\
1,6\end{array}$ \\
\hline$p 29-D C 5(p T C 8)$ & $\begin{array}{l}\text { ПЕП } \\
\text { ПЕПФО }\end{array}$ & $\begin{array}{r}3200 \\
8,7\end{array}$ \\
\hline$p 29-D C 5(p T L 1)$ & $\begin{array}{l}\text { ПЕП } \\
\text { ПЕПО }\end{array}$ & $\begin{array}{l}1600 \\
1800\end{array}$ \\
\hline$p 29-D C 5$ & $\begin{array}{l}\text { ПЕП } \\
\text { ПЕПФО }\end{array}$ & $\begin{array}{l}0,0 \\
0,0\end{array}$ \\
\hline
\end{tabular}

Выращивание трансформированных штаммов для определения активности проводили параллельно в жидких средах ПЕП, не содержашей специальных добавок неорганического фосфата, и ПЕПФО, содержа. щей однозамещенный фосфат калия в концентрации 1 г/л, т. е. в условиях дерепрессии и репрессии репрессибельной кислой фосфатазы. При этом 99-100\% клеток культуры в стационарной стадии роста сохраняли плазмиды. В качестве контрольного использовали штамм DC5 с нормальной активностью АИР-карбоксилазы. Показапю, что у трансформантов обоих типов на среде ПЕП удельная активность АИР-кар. боксилазы приблизительно на три порядка превышает таковую у штамма дикого типа. В то же время присутствие в культуральной среде из- 
бытка неорганческого фосфата снижает почти в 400 раз уровень активности у штаммов, содержащих плазмиду $p T C 8$, но практически не оказывает влияпия на его величину у трансформантов, содержащих плазмиду $p T L 1$, и штамма дикого типа. Этот факт является хорошим подтверждением того, что у полученных тралсформантов экспрессия гена $A D E 2$ находится под контролем промоторов структуршых генов репрессибельной кислой фосфатазы в одном случае и конститутивной — в другом. Кроме того, результаты измерелия активности впервые позволили достаточно точно определить степень репрессии промотора PHO5 нзбытком неорганического фосфата. Определение этой величины на ословании активностей репрессибелыно̆ кислой фосфатазы, измеренных в условнд репрессии и дерепрессии, с той же степенью точности невозмoжilo піз-за ;остаточно высокого фонового уровня активности констнтутнвной кислой фосфатазы.

Полученные результаты свидетельствуют о потенциальной возможности использовапия получених нами векторов экспрессии $p M S 46$ и $p B G 10$ для создапия штаммов дрожжей - продуцентов чужеродных белков. Это особенно важно в связи с тем, что промотор РНОЗ не нашел пока еще применения в биотехнологических исследованиях. Определяющим в выборе промотора ция решения конкретной экспериментальной залали может оказаться то обстоятельство, что промоторы PHO5 и PHO3 обеспечивают уровни экспрессии одного поряқка, по

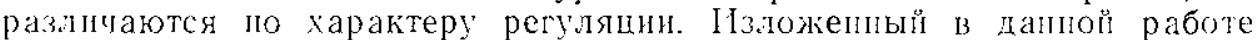
метод с использованием гена $A D E 2$, по пашему мненио, может быты с успехом применен для сравнительно̆ оценки эффектиности различгых грожжевых промоторов.

Цругим, па паш взгляд пе менее важным результатом продсланной

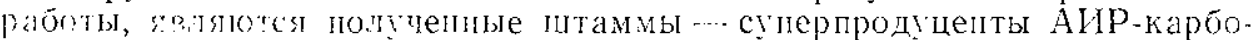

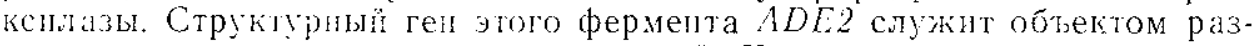

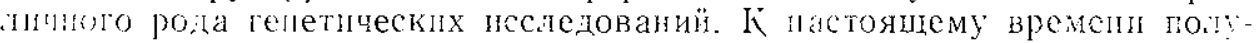

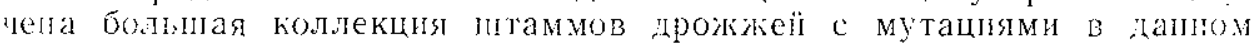
гене, пследуотся явленя межалпельой комплемептация, рекомбина-

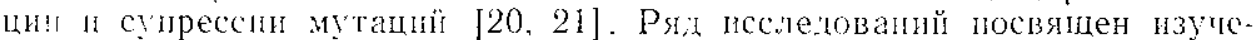

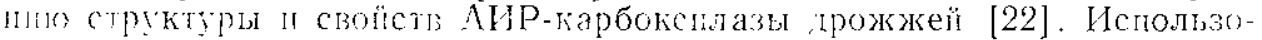

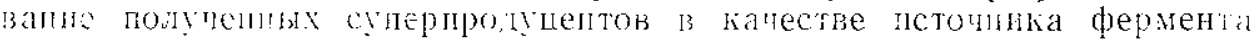
песомиенно позволит упросит схему его онистии и вылелять АНР-карбокснлазу в rораз.и боньшіх количестрах. Это должно способствонаты

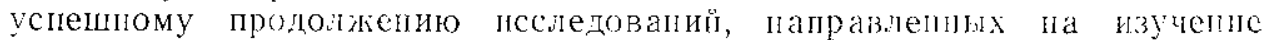
структурных іл функционалыных особенностей АИР-карбоксилазы, а

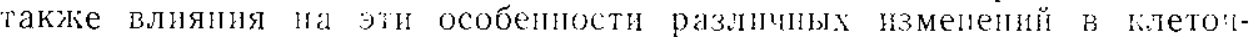
I0) геноме.

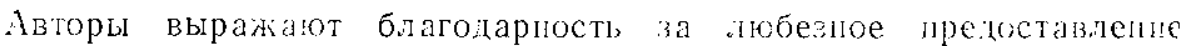
нспользованиых в пастоящей работе уникалыны препаратов В. Д. Домкину, Т. Р. Костпковой, В. А. Вейко и $\Lambda$. Xиниену, а также Д. А. Гор-

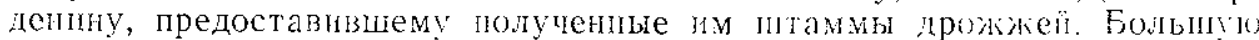

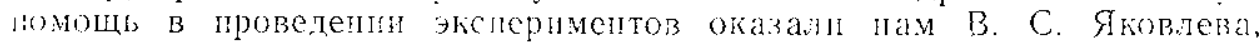
6. Н. Ковалева „ Ю. А. ПТ.ивния.

YEAST EXPRESSION VECTORS BASED ON PHO3 AND PHO5 PROMOTERS ()I SACCHAROMICES CEREVISIAE: CONSTRUCTION. RELATIVE EFFICIENCY, USE FOR OVERPRODUCTION OF AMINOIMIDAZOLE CARBOXYLASE

K. V. Ostanin, T. M. Smirnova, A. N. Myasnikov,

D. A. Gedvilaite, K. V. Sasnauskaus, M. N. Smimon

Zhdanov State University, Leningrad

Su m m ary

1 series of yeast expression vectors based on promoters of PHO3 and PHO5 genes and lranscription terminator region of the PHO5 gene have been constructed. One of the vectors incorporates the site of PHO5 coding for the structure of the leader peptide. 
The promoter region of these expression vectors is flanked by a fragment of the pUC19 polylinker containing unique restriction sites for EcoRI, SacI, KpnI and Smal. The efficiency of these vectors was tested in a model study in which they have been used to overproduce the product of yeast $A D E 2$ gene-aminoimidasole carboxylase. The specific activity of this enzyme in yeast transformants was about 1000 times higher than in wild type yeast strains.

1. Two yeast acid phosphatase structural genes are the result of a tandem duplication and show different degrees of homology in their promoter and coding sequences / B. Meyhack, W. Bajwa, H. Rudolph, A. Hinnen // EMBO J.-1982.-1, N 6.P. $675-680$.

2. Kramer $R$. D., Andersen $N$. Isolation of yeast genes with mRNA levels controlled by phosphate concentration// Proc. Nat. Acad. Sci. USA.- 1980.-77, N 11.- P. 65416545 .

3. The nucleotide sequence of the yeast PHO5 gene: a putative precursor of repressible acid phosphatase contains a signal peptide/K. Arima, T. Oshima, I. Kubota et al./! Nucl. Acids Res.-1983.-11, N 6.- P. 1657-1672.

4. Structural analysis of the two tandemly repeated acid phosphatase genes in yeast / W. Bajwa, V. Meyhack, H. Rudolph et al. // Ibid. - 1984.-12, N 20.- P. 7721-7739.

5. Boyer P., Steyn-Parve E. P. Isolation and purification of acid phosphatase from baker's yeast Saccharomyces cerevisiae // Biochim. et biophys. acta.-1966.-128, N 2-P. $400-402$.

6. In vitro synthesis of repressible acid phosphatase. Identinication of multiple mRNAs and products / K. A. Bostian, J. M. Lemire, L. E. Cannon, H. O. Halvorson // Proc. Nat. Acad. Sci. USA. - 1980-77, N 7.- P. 4504-4508.

7. Oshima $Y$. Regulatory circuits for gene expression. The metabolism of galactose and phosphate // The molecular biology of ycast Saccharomyces / Eds .I. N. Strathern et al- - New York: Cold Spring Harbor Lab. press, 1982,- Vol. 2.- P. 487-528.

8. Regulated cxpression of a human interferon gene in yeast: control by phosphate concentration or temperature/R. A. Kramer, T. M. DeChiara, M. D. Schaber, S. Hilliker // Proc. Nat. Acad. Sci. USA-1984-81, N 1.- P. 367-370.

9. Hinnen A., Meuhack B., Tsapis $R$. High expression and secretion of foreign protein in yeast// Proc. of the Alko yeast sympos./Ed. M. Korhola--Hilsinki, 1983... P. 24.

10. Expression of hepatitis B surface antigen in yeast/A. Miyanohara, A. Toh-e, N. Chikateru et al. // Proc. Nat. Acad. Sci. USA.-1983.-80, N 1.- P. 1-5.

11. Клонирование ADE2 гена дрожжей Saccharomyces cerevisiae/K. В. Саснаускас, Г. К. Гедминене, В. И. Нактинис и др.// Докл. АН СССР.-1982.-263, № 2.C. $224-227$.

12. Ген $A D E 2$ дрожжей: первичная структура и рекомбинационное картированис / А. С. Краев, М. В. Миронова, К. В. Саснаускас и др.//16-я конф. ФЕБО: Тез. докл.- М., 1984.-С. 382.

13. Использование карбоксиаминоимидазолриботида для характеристики фосфорибозиламиноимидазолкарбоксилазы дрожжей Saccharomyces cerevisiae /3. К. Николаева, В. В. Аленин, В. Д. Домкин, М. Н. Смирнов // Биохимия.-1975.-40, № 4.C. $751-754$.

14. Fisher C. R. Enzymology of the pigmented adenine-requiring mutants of Saccharomyces and Schizosaccharomyces // Biochem, and Biophys. Res. Communs. - 1969.--34, N 1 - P. 306-310

15. Маниатис Т., Фрич Э., Сәмбрук Дж. Молекулярное клонирование.- М.: Мıр, 1984. $-479 \mathrm{c}$

16. Cloning in single stranded bacteriophages as an aid to rapid DNA sequencing / F. Sanger, A. R. Coulson, G. Barrell et al. // J. Mol. Biol.-1981.-143, N 1.-P. 161178 .

17. Нзучение мутантов по экзогенной кислой фосфатазе дрожжей Saccharomyces circ visiae / М. Н. Смирнов, Н. Г Краснопевцева, С Г Инге-Вечтомов А. А Янулайтис // Исследования по генетике.-Л. : Изд-во Ленингр. ун-та, 1974.-Вып. 5.-. C. $59-62$.

18. Hinnen A., Hicks $J$. B., Fink G. R. Transformation of yeast//Proc. Nat. Acad. Sci USA - 1978-75, N 2-P. 1929-1933.

19. Bradford $M$. A rapid and sensitive method for the quantitation of microgram quantities of protein utilizing the principle of protein-dye binding // Anal. Biochem. 1976.-72, N 3-P. 248-254

20. Анализ рекомбинапионной и комплементационной карт гена $A D E 2$ у ирожжей Saccharomyces cerevisiae / В. В. Қваша, Т. Р. Сойла, Д. А. Горденин и лир.// " щетика.-1982.-18, № 5.- С. 565-574.

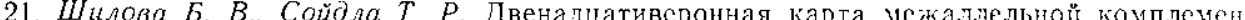
тапии локуса $A D E 2$ у дрожжей Saccharomyces cerevisiae // Исследования по генстике.- Л. : Изл-во Ленингр. ун-та, 1982,- Вып. 8.- С. 119-131.

22. Очистка и некоторые свойства фосфорибознтамннонмидазолкарбокснлазы дрожжкй Saccharomyces cerevisiae /3. K. Николаева, F. А. Пушнова, А. А. Аропитам и др. // Вести. Лениннгр. ун-та.-1982.- io 3.-С. 92-98. 